\title{
Teachers' Perspectives on Digitalized Education and Deterrents to the Use of Digital Products in Educational Processes
}

Elena, B. Puchkova ${ }^{a^{*}}$ Moscow Pedagogical State University, Moscow, Russia. E-mail: eb.puchkova@mpgu.su, https://orcid.org/0000-0001-9540-9893

Elena A. Sorokoumova ${ }^{\text {b }}$ - Moscow Pedagogical State University, Moscow, Russia. E-mail: cea51@mail.ru, https://orcid.org/0000-0002-2060-7657

Elena I. Cherdymova ${ }^{c}-$ Samara National Research University named after Academician S.P. Koroleva (Samara University, SSAU), Samara, Moscow, Russia. E-mail: cheiv77@mail.ru, https://orcid.org/0000-0002-0392$\underline{8483}$

Larisa V. Temnova ${ }^{d}$ - Lomonosov Moscow State University, Moscow, Russia. E-mail: temnova.larisa@yandex.ru, https://orcid.org/0000-0002-3417-2594

\section{Suggested Citation:}

Puchkova E. B., Sorokoumova E. A., Cherdymova E. I., Temnova, L. V. (2021). Possible risks of digitalised education and deterrents against using digital products in education processes according to teachers. Cypriot Journal of Educational Science, 16(5), 2677- 2689. https://doi.org/10.18844/cjes.v16i5.6356

Received from April 25, 2021; revised from June 15, 2021; accepted from 15 August 2021. (C)2021 Birlesik Dunya Yenilik Arastirma ve Yayincilik Merkezi. All rights reserved.

\begin{abstract}
In a globalizing world, the development of the educational field is considered the most important part of international competitiveness and improvement projects. This article aimed to research the educators' views on the use of digital technology and products in their educational process. Questionnaire was used as a research technique, with 147 participant teachers at general secondary schools in Russia. The analysis of the data was through coding. The true nature of the ecosystem of digitalized education was fully covered by the authors in this study. According to educators, the main advantages of digital technology and digital technology products for the educational field are education continuity, accessibility, individualization, freedom of choice, social equality for students and quality of education. Authors of this article revealed that deterrents against using digital products and digital technology in education processes in teachers' opinion are lack of motivation, funds, knowledge and methodology.
\end{abstract}

Keywords: students, schoolteachers, school educators, pedagogues, educational settings, educational environment, digital products, digital technology.

* ADDRESS FOR CORRESPONDENCE: Elena A. Sorokoumova, Department of Labor Psychology and Psychological Counseling, Moscow Pedagogical State University (FSBEI VO MPGU), Moscow, Russia.

E-mail address: cea51@mail.ru 
Puchkova E. B., Sorokoumova E. A., Cherdymova E. I., Temnova, L. V. (2021). Possible risks of digitalised education and deterrents against using digital products in education processes according to teachers. Cypriot Journal of Educational Science, 16(5), $2677-2689$. https://doi.org/10.18844/cjes.v16i5.6356

\section{Introduction}

In a globalizing world, the development of educational field is considered the most important part of international competitiveness improvement project. There has been a unique education system in Russia since socialism, the system that was developed according to national specificities (Andreeva, 2002; Kozlov, 2000; Golubkin, 2005). Alongside the economic developments, which happened in the digitalisation period, financial situation as well as education process management system evolved. The State education policy has changed radically in the last ten years in Russia (Kuptsov, 2009; Khavenson \& Carnoy, 2016; Barber \& Murshed, 2008; Mironov, 2007; Carnoy et al., 2017; Kalugina et al., 2018; Glotova \& Samokhvalova, 2019; Kvon et al., 2019; Piralova et al., 2020; Nguyen et al., 2021).

New conditions of education existence and development as a system require new approaches to its provision and operation. In our opinion, seeing education system as an ecosystem might be the methodological approach needed. The ecosystem of educational environment is a persistent correlation of all subjects that participate in the process of learning and educating. Digital educational environment includes digital technology and digital products, which has the potential ability to dramatically influence the sustainability of educational ecosystem by changing and transforming it, influencing the interaction of all participants in the educational process. The analysis of how exactly the digital technology implementation influences the original educational ecosystem must be made. Thus, online technology is being actively developed in Russian educational system currently and this process is highly supported by the Russian government, which also has its disadvantages (Gerova, 2014; Vinnik, 2012; Kirilova, 2011; Mikhaleva, 2019; Puchkova et al., 2019; Sorokoumova, 2019; Bayanova et al., 2020).

Modern interactive information technology (IT) educational environment of any educational institute should be based on didactic and scientific and technical support of effective forms, techniques and technology of training, which is a set of IT educational complexes (Kolganov, 2007b; Kuzhevskaya, \& Smyk, 2019; Bayanova et al., 2019b; Ivanova \& Rudinskiy, 2010). Implementation of any new education technology in any country is only available with the governmental support. Any sort of new developments, especially when it comes to educating new generations is bound to fail if it runs counter the education politics of the state (Kolganov, 2007a; Leshchinsky et al., 2011; Tekulova, 2019).

The crossroad situation, which the modern education found itself in nowadays, is determined by the inconsistency of society and education system requirements for scientific-educational activity. As a result, we get the uncertainty of values transferred to the educational institutes as a subsystem of the society (Robert, 2001; Sviryaeva, 2009; Ursova, 2006; Yuhta, 2017; Rabinovich et al., 2020). Therefore, Russian education is now undergoing some active changes. With the process of integrating Russian education system into the global one, educational institutes face the need of following modern trends, one of which is the use of digital and online technology in education. Remote education also creates several difficulties for the teachers that are involved in it, such as lack of training in the use of digital technology in their work, lack of documentary database in Russian educational field for the technology use and many more (Slikishina, 2012; Karagozov, Uvarov \& Ryzhova, 2018; Kovrigina \& Markova, 2014; Markova, 2014; Choshanov, 2018; Bayanova et al., 2019a; Yermilova et al., 2019; Tugun et al., 2020). Educational innovations should in some way be connected with digital technology. Thus, we can highlight the technology that brings the novelties specifically to the educational process - distance 
education, digital educative games, mass online courses, webinars, usage of "smart" training manuals, digital simulators etc.

\subsection{Research Objective and Structure}

The main objectives of this study were to identify the level of teachers' confidence towards the use of digital education technologies, to learn the teachers' views on the role of internet-resources in the educational process, to analyze the teachers' views on advantages, deterrents, and risks of digital education.

\section{Methods and Materials}

\subsection{Participants}

The sample consisted of 147 teachers at general secondary schools in Russia, with work experience from 3 to 23 years. The participants were selected to represent the Russian population. Therefore, the research's sampling method was purposive sampling.

\subsection{Data collection method}

The data for this research was collected with the help of questionnaire. As we developed the tools for this study, the nominal and ordinal scales were used as well as open questions. Advantages of digital education were researched through the open questions. Disadvantages and risks of digital education were revealed through the open questions.

\subsection{Data collection procedure}

The first stage of the research was conducted through questionnaires. A list of following questions, the basis of the questionnaire, was offered to the educators:

1. What is your length of service?

2. Which form of digital technology use do you find acceptable in education:

- students using gadgets to record classes.

- students using gadgets to photograph the necessary materials (timetable, study manuals etc.)

- students using gadgets during the classes, in order to find the right answer.

- students using gadgets during the tests and examinations;

- students using gadgets during project works.

3. How much do you use Internet resources in your work?

- to prepare for classes;

- to prepare reports and presentations;

- to prepare for video-conferences; 
- in order to communicate with students;

- to communicate with other teachers and administration.

4. How do you usually communicate with students in the Internet?

- communicate in social media;

- communicate via e-mail;

- communicate in Skype;

- else.

5. What matters do you usually discuss with students when communicating in the Internet?

- discuss organisational matters;

- discuss preparing digital products or projects;

- discuss conducting research;

- else.

6. Why do you like this sort of communication?

7. How often do you use different sorts of visual materials in your classes?

- I use it almost every class;

- I use it in some classes;

- I almost don't use it.

8. If you use visual materials in one way or another in your classes, why do you?

9. Do you think that using visual materials should be obligatory in any class?

10. Have you had a chance to participate in any educational online course recently?

11. Have you had a chance to work on your own online courses in the recent years?

12. If you are not satisfied with it on any level, why?

13. If you haven't had a chance to work on your own online courses, why?

14. What problems of participants evaluation might teachers come across throughout online courses?

15. To what extent are you ready to use digital technology and products today?

- quite ready;

- almost completely not ready;

- not ready;

- else.

16. What advantages and disadvantages of digital products and technology do you see in your work? 
17. How do you think, what is lacking? What is keeping you from using digital technology?

18. If you think that online education could never possibly compete with traditional education, then explain why precisely you think that way?

19. Nowadays there is an opinion that online education might in the future displace traditional education. How do you feel about this point of view?

20. Would you want to better learn digital technology?

21. In what way would you prefer to go through further training in the area of digital education?

On the second stage the pilot study was conducted. Through pilot study the following was revealed: the majority of teachers (79\%) has participated in some sort of online courses. The survey of this group of teachers showed the following advantages of online courses: time and location convenience (91\%), accessibility (84\%), visuality (84\%), high professionalism of educators (79\%), the novelty of presentation (79\%), availability of practice questions (13\%).

Following disadvantages were revealed by the teachers who participated in the survey: lack of personalized approach to students (79\%), lack of live communication with the course creators (27\%), groups forming not in accordance with participants' baseline knowledge and preparedness (13\%), technical issues and errors during the educational process were also included among the disadvantages of digital education (13\%)

\subsection{Analysis}

In analyzing the data for this research, the researchers coded the responses from the open questions in the questionnaire. The researchers thereafter make a visual representation of the responses from the participants.

\section{Results}

\subsection{Specifics of Educators' View on Digital Technology and Digital Products in Educational Process}

Throughout this research following was revealed: female teachers (71\%) were more ready to create their own online courses, than male teachers (61\%). Among the teachers who already use digital technology and products $41 \%$ are ready to start creating their own online course. Only $32 \%$ of teachers were not ready to create an online course of their own and $27 \%$ of them were not sure but said that they would less likely do so at this point.

The survey of teachers who were advocating the digital technology and digital products in the educational field, showed that teachers see the following characteristics of digital products (see Figure 
1).

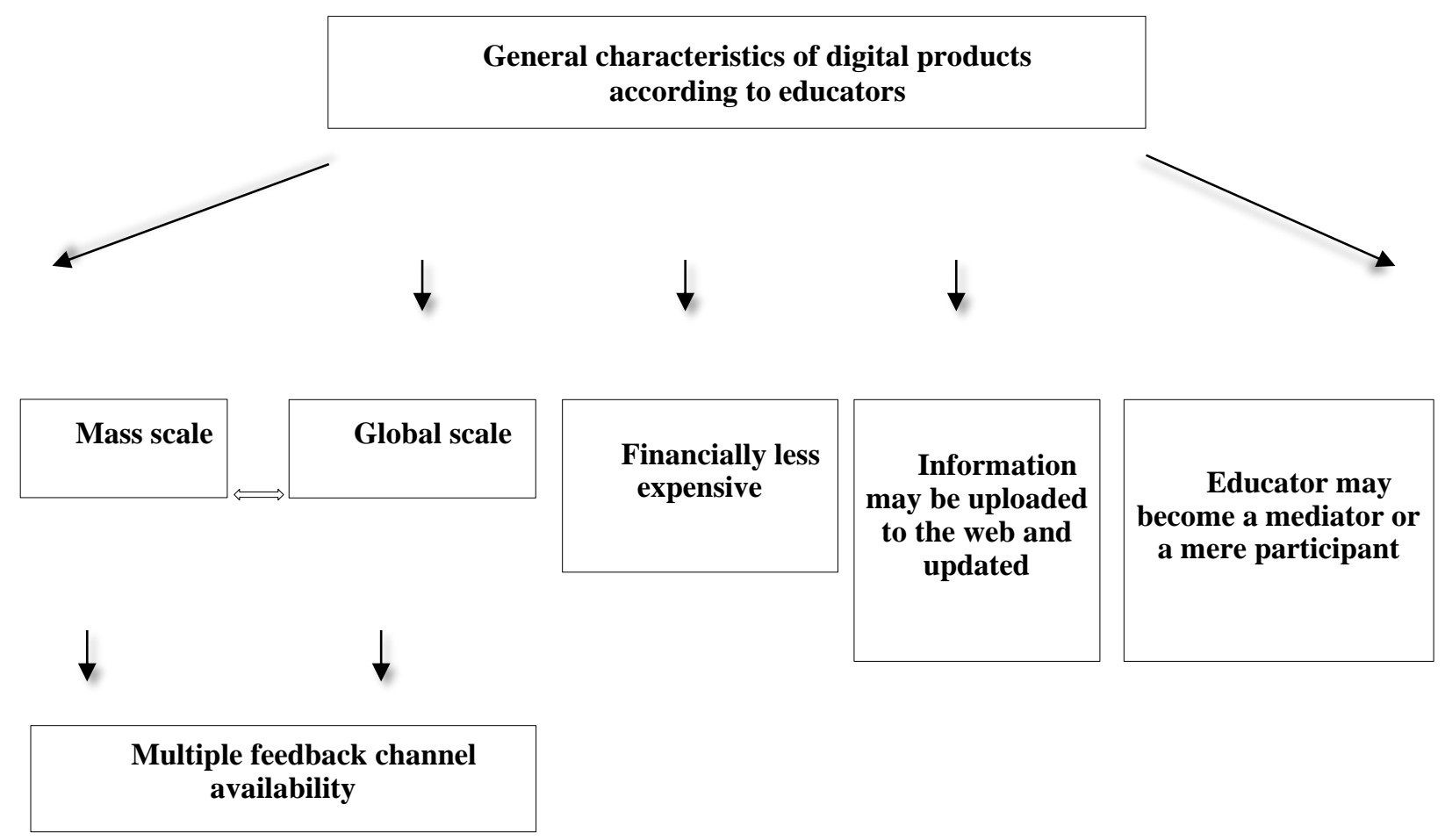

Figure 1. General characteristics of digital products according to educators

Digital technology in education according to teachers who participated in the survey, has rightfully taken its place in the world, gaining followers (87\%) as well as opponents (13\%). Although, according to participants, both those who advocate and those who oppose, admit the following advantages of this education form (see Figure 2). 


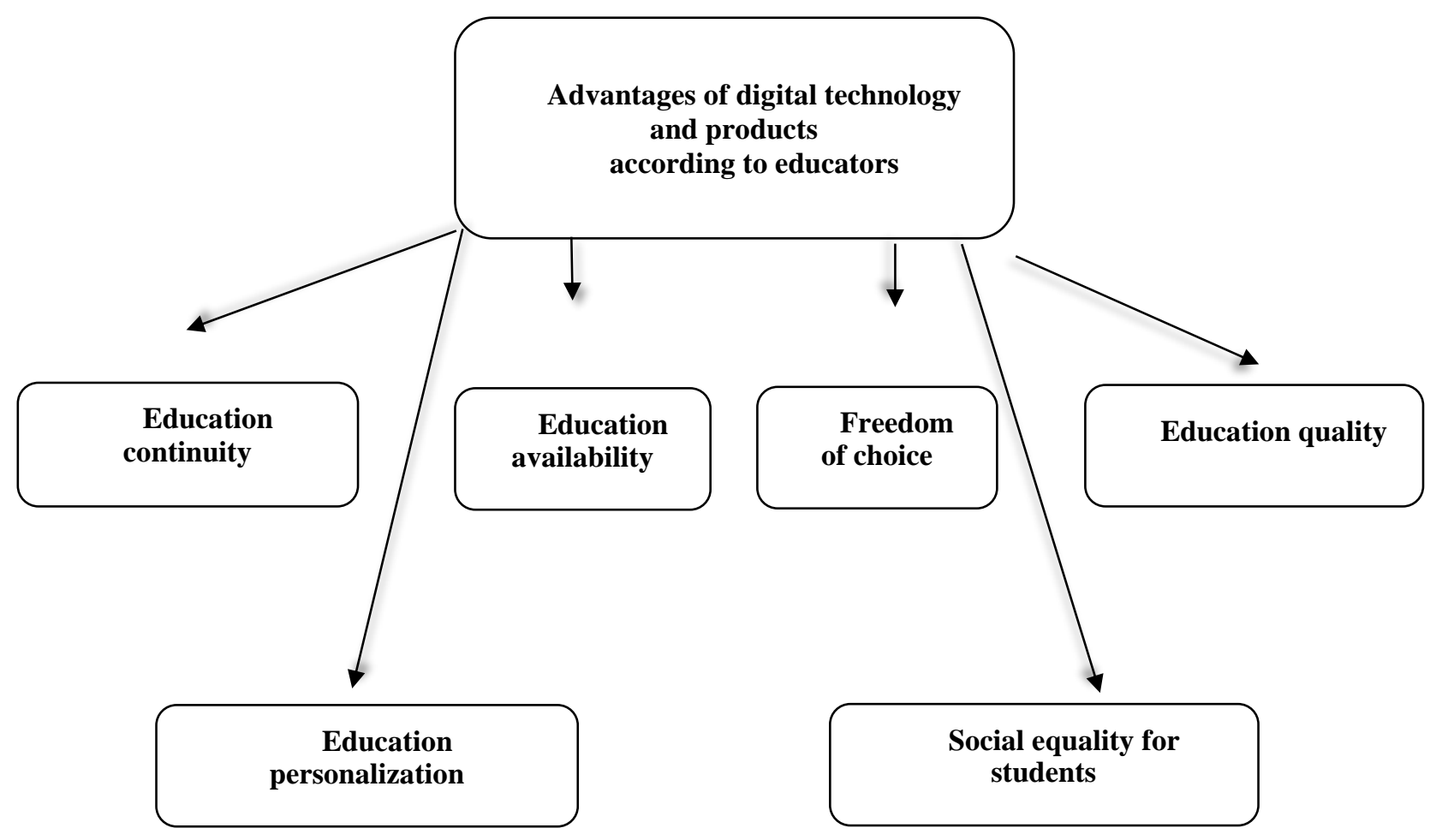

Figure 2. Advantages of digital technology and products according to educators

Analyzing the reasons of teachers' reluctance of creating their own online courses, we received the following results. More than half of interviewees (57\%) answered that they don't do it due to lack of time, $31 \%$ of interviewees think, that direct communication with the students is needed, in order to keep the educational ecosystem intact, $6 \%$ lack the necessary knowledge about the digital technology and online education to be able to create their own online course, $5 \%$ of teachers noted that they have technical issues and $1 \%$ of interviewees feel that the main reason is just unwillingness to do this kind of activity.

Furthermore, the majority of teachers feel, that lack of motivation affects the willingness to create online courses. Following deterrents against creating online courses were revealed: lack of methodology for creating courses (31\%), lack of necessary knowledge and skills (21\%), lack of motivation (19\%), advocating the traditional form of education only, without any online technology (13\%), lack of funds to buy the necessary gadgets (13\%), lack of understanding on how to make an online course for their subject (3\%) (see Figure 3). 

digital products in education processes according to teachers. Cypriot Journal of Educational Science, 16(5), $2677-2689$. https://doi.org/10.18844/cjes.v16i5.6356

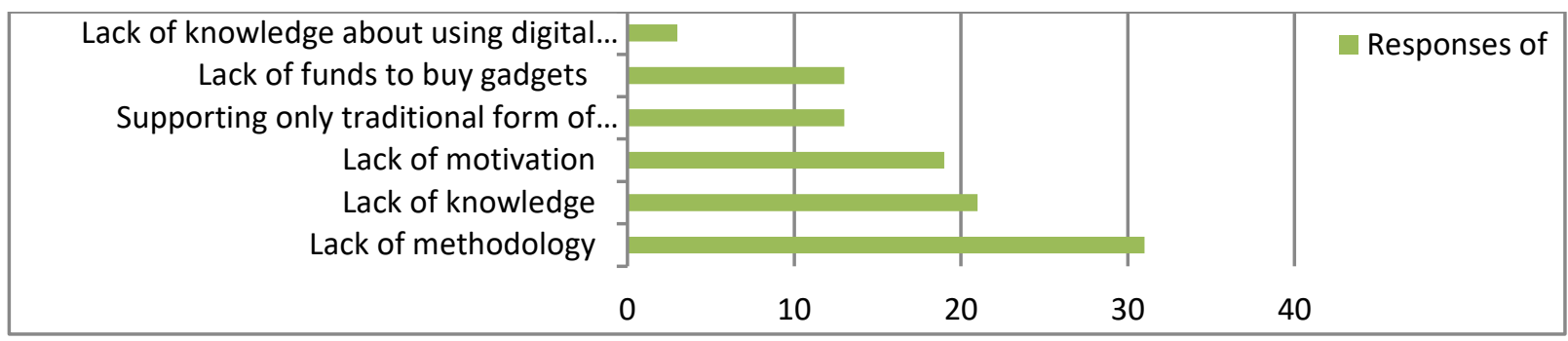

Figure 3. According to teachers, what stops them from creating their own online courses with usage of digital technology (in \%)

From the results of the conducted research, we see that $41 \%$ of teachers are quite satisfied with the process of creating online courses, $43 \%$ of participants were more satisfied than not, $13 \%$ - more unsatisfied than satisfied and only $3 \%$ were totally unsatisfied. Analyzing the issues that teachers came across during their online course creating experience, we noted the following: problem with assessment of students' knowledge (53\%), problem with communication with students (37\%), students' low motivation (21\%), problem with attention among students (13\%), technical issues (11\%), no issues at all (11\%).

Answering the questions on what problems with assessment of students' knowledge did they come across, teachers noted the following: it was hard to reveal the real level of understanding the material given (43\%), the results of assessments were unreliable (39\%), it was easy for students to cheat during the tests and assignments (13\%).

One of the big disadvantages of online courses is unreliability of the students' assessments. As a result, teachers experience the issue with revealing the level of students' comprehension of the material given and cannot be completely sure whether students do the assignments and tests on their own, which is how the assessment is usually made. The main issues with student-teacher communication are following lack of visual contact (34\%), lack of dialogue (37\%) during the educational process. These are the reasons for the assessment problems, including the unreliability of results, the teachers have during online courses.

The majority of the participants $73 \%$ think that online education will exist parallel to traditional education, $16 \%$ think that online education cannot compete with traditional education and only $11 \%$ think that online education is the future.

According to the results, we may say, that traditional education is indispensable due to direct personal contact between a student and a teacher and experience exchange, whereas online education is necessary due to its accessibility, mobility and time saving. 


\section{Discussion}

Today mass scale open education is about to be integrated into international educational processes. Given the existence of obvious advantages and disadvantages of modern education, the debate on feasibility of online educational field and its risks and threats to traditional education (Bayanova et al., 2019a)

The question on whether online education might in the future compete with traditional education or even dispense it, is more and more popular among the researchers who study the problems of education. Some of these researchers find the distance form of education basically defected and reduced.

Scientific community and education officials are now facing some critical issues of certifying and quality control of this sort of courses and the methodology of online education, digital technology and digital products.

The change in educational field is inevitable, although these changes should not touch the fundamental basics of educational field in order to keep the current educational environment intact, including the direct interaction in the triad "student - teacher - parent". We assume, that implementation of new digital technology and digital products require revision of the traditional educational techniques, designing new education technologies, which could at the beginning complement traditional education and subsequently dispense some outdated techniques.

The research concludes that digital technology and digital products is the new reality of present, and there is no escaping it. The situation with implementing digital technology in educational field is ambiguous, but one thing is clear - this technology has the ability to change the educational ecosystem and have certain risks and threats (Khavenson \& Carnoy, 2016).

Therefore, online education is an innovative educational model, based on usage of new digital technology and digital products (Rabinovich et al., 2020). This new form of education is rapidly entering our lives, affecting the principles of existence and preservation of traditional education.

\section{Conclusions}

Online education is a form of education where teachers, students and parents interact with each other remotely, and all components of educational process (goals, content, techniques, organizational forms, educational tools) are executed by digital technology and digital products or other tools, which imply interactivity. According to experts, the development of online education can change the usual ecology of educational environment, dramatically transforming it, for example into the form of teaching specific subjects.

Regarding the dispense of traditional education, opinions divide from full replacement of traditional education by online education to parallel existence of both in different ratios. The most common view 
is a mixed form of education. A small part of experts think that critical changes are unlikely to happen because of the need for significant investment, lack of regulatory framework, teachers' passivity of thinking, difficulties with assessment and control of given education by the people involved and more.

Specifics of online education received mixed opinions by experts and users. The nature of interaction between a student and a teacher in this form is questionable. Finding online interactions equal or unequal to traditional "live" interaction between a student and a teacher determine the attitude towards online education and its future perspectives.

Research results analysis allows us to define some general conclusions. The vast majority of teachers, who participated in the study, consider online education to have a good prospect, but only if traditional education is preserved and is only complemented by the online form. In this case we will have the opportunity to compensate for the disadvantages of the online education and broaden the possibilities of the traditional form. More than half of the teachers use online courses for their further training - the age in this group varies from 22 to 35 years old. Teachers from 25 to 45 years old are, according to this study, more ready to use digital technology, digital products and are more ready to create online courses of their own.

Furthermore, more than half of female teachers are ready to create and promote online courses. More than half of all participating teachers, who use digital technology and digital products are not certain at this point whether they want to create their own online courses or not. More than half of all participating teachers, who have participated earlier in any sort of online courses, are ready to create their own online course. Teachers, who have started creating their own course by advice or by their own choice, are most satisfied with it. The least satisfied with creating the own course group is the group of teachers who were made to do so by the administration of their school.

\section{Acknowledgment}

The research was carried out within the framework of the implementation of the scientific research "Development of psychological and pedagogical foundations for standardization of digital educational products/technologies" by the Moscow State Pedagogical University in 2021 at the expense of the federal budget.

\section{References}

Andreeva, I.N. (2002). History of education and pedagogical thought abroad and in Russia. Moscow: Academy. https://elibrary.ru/item.asp?id=22511392

Barber, M. \& Murshed, M. (2008). How to achieve stable high-quality teaching in schools. Lessons from the analysis of the best school systems in the world. Educational issues, 3, 7-11. http://ecsocman.hse.ru/data/2011/05/06/1268032922/1.pdf 
Puchkova E. B., Sorokoumova E. A., Cherdymova E. I., Temnova, L. V. (2021). Possible risks of digitalised education and deterrents against using digital products in education processes according to teachers. Cypriot Journal of Educational Science, 16(5), $2677-2689$. https://doi.org/10.18844/cjes.v16i5.6356

Bayanova, A.R, Sabaeva, E.K., Sakhipova, Z.M., Zatsepina, M.B., Tararina, L.I., Votinov, A.A. \& Ilkevich, K.B. (2019a). Educational Environment Ecology as Factor of University Teacher Health Saving in Context of Education and Science Reforms in Modern Russia. Ekoloji, 28(107), 4937-4941. http://www.ekolojidergisi.com/article/educational-environment-ecology-as-factor-of-university-teacherhealth-saving-in-context-of-7072

Bayanova, A.R., Kuznetsov, V.V., Merculova, L.V., Gorbunova, L.N., Pervozvanskaya, O.A., Shalamova, O.O. \& Vorobyova, C.I. (2019b). Student Performance Interrelation With Gadget Use At Lessons. Journal of Environmental Treatment Techniques, 432-437. http://www.jett.dormaj.com/docs/Volume7/Issue\%203/Student\%20Performance\%20Interrelation\%20wi th\%20Gadget\%20Use\%20at\%20Lessons.pdf

Bayanova, A.R., Sivova, I.V., Kamasheva, Y.L., Popova, O.V., Semyanov, E.V., Shagieva, R.V. \& Yusupov, I.M. (2020). Student online services consumption: Routine practices or mistrust to digital service? Contemporary Educational Technology, 11(1), 47-54. https://eric.ed.gov/?id=EJ1234836

Carnoy, M., Marotta, L., Louzano, P., Khavenson, T., Guimaraes, F.R.F. \& Carnauba, F. (2017). Intranational Comparative Education: What State Differences in Student Achievement Can Teach Us about Improving Education - the Case of Brazil. Comparative Education Review, 61(4), 726-759. https://www.journals.uchicago.edu/doi/abs/10.1086/693981

Choshanov, M.A. (2018). Didactics of the Digital Age: From Teaching to Engineering Learning. Computer science and education, 9, 53-62. https://elibrary.ru/item.asp?id=36605566

Gerova, N.V. (2014). Requirements for the results of mastering the basic educational programs of bachelor's and master's degrees for students in the field of studying computer science and ICT. Pedagogical education in Russia, 8, 94-98. https://cyberleninka.ru/article/n/15619418

Glotova, M.Yu. \& Samokhvalova, E.A. (2019). Bloom's digital taxonomy and a model of digital transformation of education in the educational process of a university. Computer science and education, 6, 42-48. https://info.infojournal.ru/jour/article/view/419?locale=en US

Golubkin, V. (2005). The goal of the DO is to increase intellectual capital. Distance and virtual learning, 11(1), 911.

Ivanova, O.V. \& Rudinsky, I.D. (2010). Methodology of a multicriteria approach to assessing the professional competence of specialists (article). Izvestiya BGA RF: Psychological and pedagogical sciences: scientific journal. Kaliningrad, 3-4(13-14), 20-29. https://elibrary.ru/item.asp?id=16284214

Kalugina, O.A., Vasbieva, D.G., Shaidullina, A.R., Sokolova, N.L. \& Grudtsina, L.Y. (2018). ESP blended learning based on the use of smart coursebook. XLinguae, 11(2), 445-454. https://elibrary.ru/item.asp?id=35034983

Karagozov, S.D., Uvarov A.Yu. \& Ryzhova N.I. (2018). Towards a digital school model. Computer science and education, 7, 4-15. https://elibrary.ru/item.asp?id=36265976

Khavenson, T. \& Carnoy, M. (2016). The unintended and intended academic consequences of educational reforms: the cases of Post-Soviet Estonia, Latvia and Russia. Oxford Review of Education, 42(2), 178-199. https://www.tandfonline.com/doi/abs/10.1080/03054985.2016.1157063

Kirilova, G.I. (2011). Questions of the formation of an information educational environment for vocational education. Kazan pedagogical journal, 2, 114-119. https://cyberleninka.ru/article/n/15122891

Kolganov, E.A. (2007a). Internet technologies. Ufa: Tutorial.

Kolganov, E.A. (2007b). Quality of distance learning. Higher education: current trends, problems and development prospects: Materials of the All-Russian scientific method. Ufa: UGAES. 
Puchkova E. B., Sorokoumova E. A., Cherdymova E. I., Temnova, L. V. (2021). Possible risks of digitalised education and deterrents against using digital products in education processes according to teachers. Cypriot Journal of Educational Science, 16(5), $2677-2689$. https://doi.org/10.18844/cjes.v16i5.6356

Kovrigina, V.A. \& Markova, N.I. (2014). Prospects for the development of online learning in the Russian educational space. Modern higher education: an innovative aspect, 3, 68-74. https://cyberleninka.ru/article/n/18318283

Kozlov, A.V. (2000). On the question of the interaction of pedagogical theory and practice in the work of the school. Pedagogical thought and education of the XXI century: Russia-Germany (pp. 38-45). Orenburg. https://cyberleninka.ru/article/n/16910691

Kuptsov, V.I. (2009). Education, science, worldview and global challenges of the XXI century. Saint Petersburg: Aleteya. https://www.labirint.ru/books/217442/

Kuzhevskaya, E.B. \& Smyk, E.I. (2019). Application of distance learning technologies in the modern educational process: pros and cons. Economic security bulletin, 3, 376-378. https://cyberleninka.ru/article/n/primenenie-distantsionnyh-tehnologiy-obucheniya-v-sovremennomobrazovatelnom-protsesse-za-i-protiv

Kvon, G.M., Vaks, V.B., Kalimullin, A.M., Bayanova, A.R., Shaidullina, A.R., Dolzhikova, A.V. \& Lapidus, N.I. (2019). Developing the Informational and Digital Environment of a University: Problem Analysis and Assessment. Eurasia Journal of Mathematics, Science and Technology Education, 15(10), 1841-1848. https://www.ejmste.com/article/developing-the-informational-and-digital-environment-of-a-universityproblem-analysis-and-assessment-7719

Leshchinsky, M.B., Martynenkov, V.V., Pestrikov, A.M. \& Rudinsky, I.D. (2011). Virtual-full-scale training complexes for training specialists in the field of innovative technologies. Information technology for modeling and control, 2(67), 128-134.

Mikhaleva, O.V. (2019). Formation of competence in the field of intercultural communication among future bachelors in a digital educational environment: PhD Thesis. Moscow: Institute of Educational Management of the Russian Academy of Education. https://tinyurl.com/knbnzvdc

Mironov, V.V. (2007). Russia in the Global World: Domestic Education and the Bologna Process. Common sense, 2(43), 43-51. https://tinyurl.com/knbnzvdc

Nguyen, T.H., Prokopyev, A.I., Lapidus, N.I., Savostyanova, S.A., \& Sokolova, E.G. (2021). Magic in healing practice: A case study in Vietnam and its philosophical assessment. XLinguae, 14(3), 164-176. http://xlinguae.eu/files/XLinguae1_2019 10.pdf

Piralova, O.F., Gerasimenko, S.A., Kuznetsov, V.V., Popova, O.V., Subbotin, G.V., Kolomyts, O.G., \& Mashkin N.A. (2020). Gaming Industry Trends in new Generation Specialist Training in University Environment. Journal of Environmental Treatment Techniques, 8(3), 1132-1135. https://www.openrepository.ru/article?id=565869

Puchkova, E.B., Temnova, L.V., Sorokoumova, E.A. \& Kurnosova, M.G. (2019). The relationship between values and career orientations of modern adolescents. Psychological science and education, 24(5), 27-36. https://psyjournals.ru/files/110329/pse_2019 n5.pdf\#page=36

Rabinovich, P.D., Zavedensky, K.E., Kushnir, M.E., Khramov, Yu.E. \& Melik-Parsadanov, A.R. (2020). Digital transformation of education: from changing means to developing activities. Computer science and education, 5: 4-14. https://info.infojournal.ru/jour/article/view/537?locale=en US

Robert, I.V. (2001). Information interaction in the information and communication subject environment. Scientific notes of RAO, 5, 3-30. https://www.revistaespacios.com/a17v38n40/a17v38n40p32.pdf

Slikishina, I.V. (2012). Distance education - the beginning of the path. Information and communication technologies Pedagogical education, 4, 31-43. https://elibrary.ru/item.asp?id=21427419 
Puchkova E. B., Sorokoumova E. A., Cherdymova E. I., Temnova, L. V. (2021). Possible risks of digitalised education and deterrents against using digital products in education processes according to teachers. Cypriot Journal of Educational Science, 16(5), $2677-2689$. https://doi.org/10.18844/cjes.v16i5.6356

Sorokoumova, E.A. (2019). Self-knowledge of children of the digital generation and their psychological well-being in the learning process. Information and communication technologies in the modern educational space (pp. 58-66). Moscow: LLC "Sam Polygraphist". https://elibrary.ru/item.asp?id=42633673

Sviryaeva, M.A. (2009). Formation of basic professional competencies of an engineer in the context of distance learning: PhD Thesis. Tambov: Tambov State Technical University. https://static.freereferats.ru/ avtoreferats/01004575879.pdf

Tekulova, I.N. (2019). Digital environment as a pedagogical condition for positive socialization of students in French-speaking countries (France, Canada): PhD Thesis. Moscow: Moscow City Pedagogical University. https://tinyurl.com/2tp96nk6

Tugun, V., Bayanova, A.R., Erdyneeva, K.G., Mashkin, N.A., Sakhipova, Z.M. \& Zasova, L.V. (2020). The Opinions of Technology Supported Education of University Students. International journal of emerging technologies in learning, 15(23), 4-14. https://www.learntechlib.org/p/218460/

Ursova, O.V. (2006). Developing potential of information and communication technologies in the system of professional development of subject teachers: PhD Thesis. Velikiy Novgorod: Yaroslav the Wise Novgorod State University. https://www.topuniversities.com/universities/yaroslav-wise-novgorod-state-university

Vinnik, V.K. (2012). Using the educational electronic environment Moodle in the organization of independent work of students. Bulletin of the North Caucasus Humanitarian Institute, 1, 182-186. https://core.ac.uk/download/pdf/287488601.pdf

Yermilova, V.V., Loktionova, Y.N., Smirnov, A.V., Seregina, T.N., \& Prokopyev, A.I. (2019). The development of a personal wellbeing index -indicator of the life satisfaction. Espacios, 40(25), Article 16. https://www.revistaespacios.com/a19v40n25/19402516.html

Yuhta, N.M. (2017). Prospects for the development of distance learning in higher professional education. Scientific and educational space: development prospects: materials of the $V$ International. scientific-practical conf (pp. 106-111). Cheboksary: CNS Interactive plus. https://interactive-plus.ru/e-articles/406/Action406130038.pdf 